\title{
Effects of diet on lipolysis and its regulation
}

\author{
BY RICHARD G. VERNON \\ Hannah Research Institute, Ayr KA6 5HL
}

The amount of lipid in a fat cell (adipocyte) is determined by the rate of lipolysis as well as the rate of lipid synthesis. Both processes occur simultaneously and continuously, their relative rates determining if there is net lipid loss or accretion.

\section{REGULATIONS OF LIPOLYSIS}

Acute control. Hydrolysis of triacylglycerols is catalysed by hormone-sensitive lipase. The activity of this enzyme is enhanced by phosphorylation by cyclic-AMP-dependent kinase (A-kinase). Hormone-sensitive lipase, and hence lipolysis, is thus acutely stimulated by a variety of hormones (e.g. adrenaline, glucagon, adrenocorticotrophic hormone $(\mathrm{ACTH})$ ) and the neurohumoral transmitter, noradrenaline, which increase the adenylate cyclase-A-kinase signal transduction system. Each peptide hormone interacts with its own receptor in the plasma membrane while adrenaline and noradrenaline interact with the $\beta$-adrenergic receptor. These hormone-receptor interactions lead to dissociation and activation of the GTP-binding protein, $\mathrm{G}_{\mathrm{s}}$, which in turn leads to activation of adenylate cyclase (also located in the plasma membrane) and the synthesis of cyclic-AMP (Fig. 1). Cyclic-AMP activates A-kinase which in turn phosphorylates and activates hormone-sensitive lipase. Signal transduction through this system is modulated by noradrenaline and adrenaline acting via a second receptor, the $\alpha_{2}$-adrenergic receptor, and by prostaglandins $\left(E_{1}\right.$ and $E_{2}$ ) and adenosine, both produced within adipose tissue, and acting via their own receptors. These receptors are coupled to a second GTP-binding protein, $G_{i}$. Receptor activation leads to dissociation of $G_{i}$ which inhibits adenylate cyclase (Fig. 1). Catecholamines can, thus, both stimulate and inhibit lipolysis, the net effect depending on the relative numbers of $\beta$ - and $\alpha_{2}$-adrenergic receptors of the fat cells.

Insulin also modulates lipolysis acutely. The mechanisms have not been fully elucidated but include activation of a cyclic-AMP phosphodiesterase, possibly by increased phosphorylation (Degerman et al. 1990), which catalyses the degradation of cyclic-AMP and so reduces A-kinase activity. Insulin is also thought to activate the phosphatases which dephosphorylate and inactivate hormone-sensitive lipase (Stralfors \& Honnor, 1989).

Recent research is revealing further forms of control for what was once a relatively simple system. A-kinase, and a specific $\beta$-adrenergic receptor kinase phosphorylate and uncouple the $\beta$-adrenergic receptor from $G_{s}$ (Roth et al. 1991). A-kinase can also phosphorylate and activate cyclic-AMP phosphodiesterase, providing a feedback loop (Degerman et al. 1990). Another kinase has been discovered which is stimulated by AMP (Hardie, 1989). This kinase phosphorylates hormone-sensitive lipase on a serine next but one to that phosphorylated by A-kinase; phosphorylation on either serine prevents phosphorylation on the other (Garton et al. 1989). Since increased concentrations of palmitoyl-CoA lead to activation of this AMP-stimulated kinase (Hardie, 1989), this 


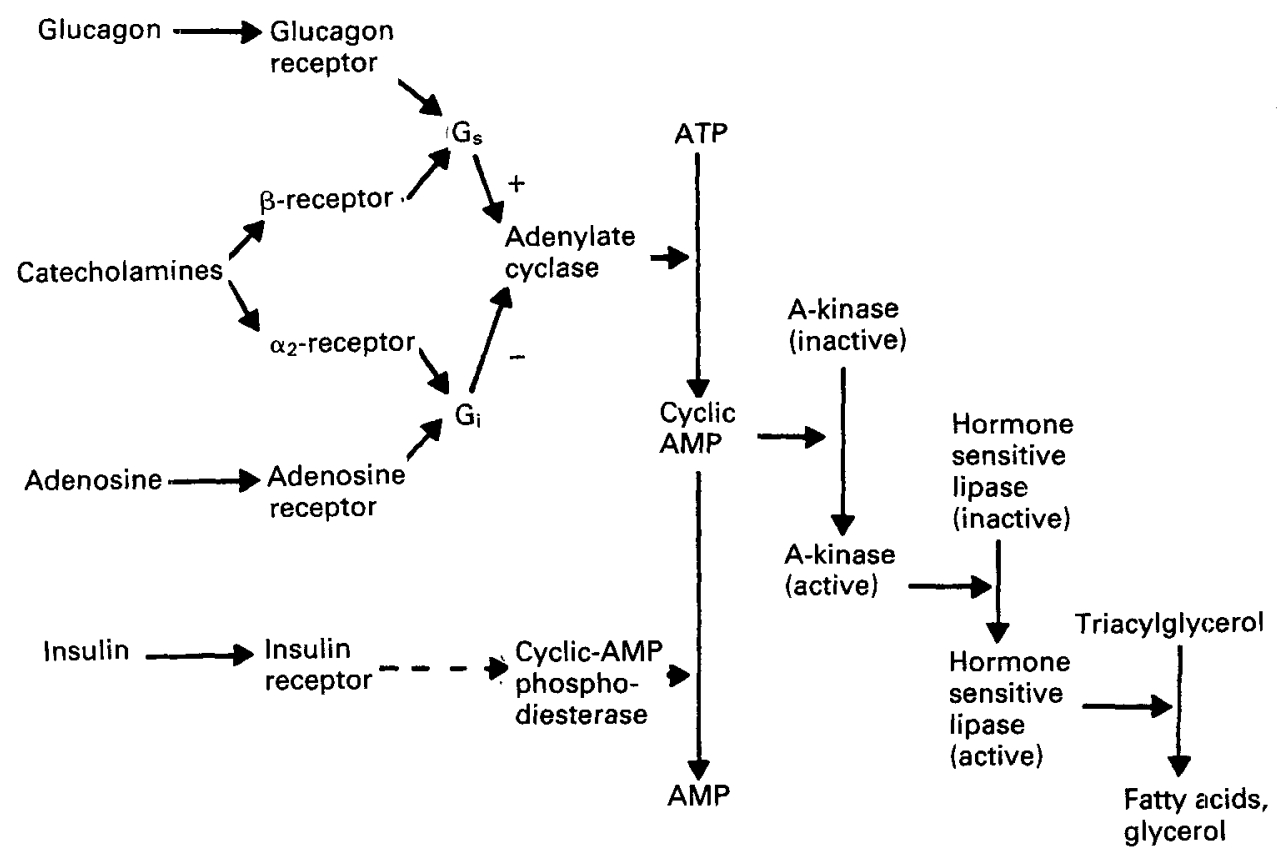

Fig. 1. Lipolytic signal transduction cascade. + , activation; - , inhibition.

enzyme may also be part of a feedback loop; an accumulation of unesterified fatty acid in the cell leads to inhibition of lipolysis (Vernon \& Clegg, 1985). Blood flow is also important with respect to this. In blood, fatty acids are bound to albumin. When rates of lipolysis are high most of the binding sites on albumin may become occupied so that removal of fatty acid from the tissue via blood may become limiting, leading to an accumulation of fatty acids in the tissue and, hence, a diminution in the rate of lipolysis (Vernon \& Clegg, 1985).

Within the fat cell, the lipid droplet is surrounded by a filamentous structure (Slavin, 1972; Franke et al. 1987). It is now becoming apparent that in addition to activation of hormone-sensitive lipase, mechanisms exist which promote its sequestration into the membrane-like structure surrounding the lipid droplet and subsequently allow access of the enzyme to its lipid substrate. For example, disruption of cellular organization by homogenization can lead to a massive rise in the rate of lipolysis in unstimulated tissue (Oschry \& Shapiro, 1980; Ninomiya et al. 1990) while a protein, termed perilipin, has been identified on the surface of the fat droplet, which is phosphorylated by A-kinase (Greenberg et al. 1991) and is postulated to be involved in anchoring hormone-sensitive lipase to the droplet.

Chronic control. It is now appreciated that the ability of these systems, involved in the acute control of lipolysis, to transmit signals varies and is subject to chronic endocrine control. Thyroid hormones, glucocorticoids, sex steroids, growth hormone and insulin can all exert chronic modulatory effects.

Chronic exposure to growth hormone in vivo (Sechen et al. 1990) and in vitro (Watt 
et al. 1991) increases response to catecholamines; the mechanism is still unclear, but the hormone can increase $\beta$-receptor number (Watt et al. 1989, 1991), cyclic-AMP phosphodiesterase activity and at least one further component downstream of A-kinase ( $R$. $G$. Vernon and E. Finley, unpublished results). Glucocorticoids also increase $\beta$-adrenergic receptor number, but in contrast to growth hormone, decrease maximum adenylate cyclase activity (Giudicelli et al. 1989; Ros et al. 1989). Adrenalectomy increases response to adenosine (Saggerson, 1980; De Mazancourt et al. 1989). Castration in rats and hamsters decreased response to both $\beta$ - and $\alpha_{2}$-agonists but had no effect on response to adenosine (Giudicelli et al. 1989; Xu et al. 1991); the decreased response to $\beta$-agonists appears to be at least partly due to a reduction in the number of $\beta$-adrenergic receptors, and can be reversed by treatment with testosterone ( $\mathrm{Xu}$ et al. 1991). Ovariectomy reduces response to catecholamines and this can be prevented by oestradiol treatment; the mechanism, however, appears to involve a fall in adenylate cyclase activity with no change in $\beta$-receptor number being apparent (Giudicelli et al. 1989; Lacasa et al. 1991).

Hypothyroidism decreases response to $\beta$-agonists and increases response to both adenosine and prostaglandin $E_{2}$ (Malbon et al. 1988). Receptor numbers are unchanged; the effects of adenosine and prostaglandin $E_{2}$ are at least partly due to increased $G_{i}$ activity (Milligan \& Saggerson, 1990). Hypothyroidism (Engfeldt et al. 1982) and thyroidectomy (Correze \& Thibout, 1985) also increase cyclic-AMP phosphodiesterase activity of fat cells. In addition to its acute effects on lipolysis, insulin also appears to have some chronic effects; diabetes, for example, decreases sensitivity to adenosine (Saggerson, 1989) possibly due to a change in $G_{i}$ activity and decreases adenylate cyclase activity (Strassheim et al. 1990). Diabetes may also alter response to $\beta$-agonists and $\beta$-receptor number but reports are conflicting (see Vernon, 1992).

\section{EFFECTS OF DIET}

Diet, either amount or composition, can potentially influence lipolysis in several ways: by altering the serum concentration of acutely acting hormones, by altering sympathetic nervous activity and by altering membrane composition and fluidity or concentrations of chronically acting hormones, or both, thus altering the ability of fat cells to transmit signals. Lipolysis is most sensitive to nutrient availability but dietary composition can also have some effect.

Nutrient availability: fasting and refeeding. Fasting or energy restriction alter the serum concentration of a variety of hormones (Table 1) which have implications for lipolysis. However, their relative importance in this respect has been a matter of some controversy which is still not fully resolved. It is well established that serum insulin falls during the postprandial period and remains low during fasting and it is generally agreed that this facilitates lipolysis. Serum glucagon rises on fasting (Unger, 1972; Unger \& Orci, 1976; Shetty, 1990) and, hence, should promote the lipolysis of fasting. However, it has been pointed out that glucagon is only weakly lipolytic in a number of species, including man (Hales et al. 1978) and domestic ruminants (Vernon, 1980), and its lipolytic effects are readily suppressed by insulin, hence the quantitative importance of the increase in glucagon for fasting lipolysis remains uncertain.

Catecholamines are strongly lipolytic in mammals and it was thought for a long time 
Table 1. Comparison of the effects of fasting and re-feeding, and lactation and litterremoval on some factors which modulate the rate of lipolysis

\begin{tabular}{|c|c|c|c|c|}
\hline Variable & Fasting & Refeeding & Lactation & $\begin{array}{l}\text { Litter- } \\
\text { removal }\end{array}$ \\
\hline Serum insulin & $\downarrow$ & $\uparrow$ & $\downarrow$ & $\uparrow$ \\
\hline Serum glucagon & $\uparrow$ & $?$ & - & $?$ \\
\hline Serum adrenaline & $\uparrow$ & - & $?$ & $?$ \\
\hline Serum triiodothyronine & $\downarrow$ & - & $\downarrow$ & - \\
\hline Sympathetic nervous activity & $\downarrow$ & $\uparrow$ & $\downarrow$ & $?$ \\
\hline \multicolumn{5}{|l|}{ Adipocyte } \\
\hline Response to adrenaline & - & - & - & $\downarrow$ \\
\hline Sensitivity to adrenaline & $\uparrow$ & - & - & - \\
\hline$\beta$-adrenergic receptor number & $\uparrow$ & $?$ & $\uparrow$ & - \\
\hline \multicolumn{5}{|l|}{ Adenylate cyclase activity } \\
\hline Basal & - & $\uparrow$ & - & - \\
\hline Maximum & - & $?$ & $\downarrow$ & - \\
\hline $\begin{array}{l}\text { Cyclic-AMP phosphodiesterase } \\
\text { activity }\end{array}$ & $\downarrow$ & $\uparrow$ & $\downarrow$ & - \\
\hline
\end{tabular}

$\downarrow, \uparrow,-$, Concentration/activity decreased, increased or the same respectively as that found at onset of postprandial period.

that fasting must enhance sympathetic nervous activity, thereby stimulating lipolysis. However, it now appears that sympathetic nervous activity in general is decreased during fasting, although this has not been shown specifically for white adipose tissue (Barrand \& Callingham, 1983; Landsberg \& Young, 1985); a decrease in sympathetic activity is perhaps not surprising as it results in a lower metabolic rate thus conserving reserves of nutrients. However, while increased noradrenaline release from nerve endings can probably be excluded as a major lipolytic promoter during fasting, it is now apparent that adrenaline release from the adrenal medulla is under separate control (Young et al. 1984). A number of studies (e.g. Young et al. 1984; Wolfe et al. 1987; Klein et al. 1989), but not all (Jung et al. 1979), report increased plasma adrenaline concentrations during fasting and a recent study shows that this increase begins during the postprandial period (Coppack et al. 1990). In addition several studies have reported that $\beta$-adrenergic blockade (Kozlowski et al. 1985; Klein et al. 1989) or surgical denervation (Bray \& Nishizawa, 1978) during fasting prevents the rise in serum free fatty acids and glycerol (used as indices of increased lipolysis). Some earlier studies argued against a role of adrenaline in fasting-induced lipolysis (see Shetty, 1990) but the weight of recent evidence would suggest that adrenaline is of importance. Thus, it is probable that a combination of increased serum adrenaline, and perhaps glucagon, and decreased insulin concentrations all contribute to the enhanced lipolysis during a fast. The effect of fasting on local modulators of lipolysis (adenosine and prostaglandin $\mathrm{E}_{2}$ ) in adipose tissue extracellular fluid is unknown, but developments in microdialysis (e.g. Lonnroth et al. 1989) should soon provide an answer to this.

Several studies have shown that fasting increases the response and sensitivity of lipolysis to catecholamines in man in vivo (Arner et al. 1981a; Jensen et al. 1987; Wolfe et al. 1987; Klein et al. 1990); this is a chronic adaptation developing between about $15 \mathrm{~h}$ 
and $4 \mathrm{~d}$ of fasting. The factors responsible have not been elucidated, and while a fall in serum insulin and glucose contribute to the enhanced lipolytic response to catecholamines, they do not provide a complete explanation (Jensen et al. 1987; Klein et al. 1990). Also, paradoxically, an increased response to the anti-lipolytic effect of adenosine has been proposed (Peters et al. 1991).

In vitro studies with isolated fat cells or tissue pieces also reveal an increased sensitivity to catecholamines on fasting in man (Andrews, 1984), hamsters (Carpene et al. 1990) and rats (Zapf et al. 1977; Dax, 1981; Chohan et al. 1984). In addition Saggerson (1986) reported an increased sensitivity to glucagon but not ACTH in fat cells from fasted rats. Fasting did not increase maximum response to catecholamines in isolated fat cells from humans (Andrews et al. 1984), in perfused canine adipose tissue (Fredholm et al. 1973) and in some studies with rat (Zapf et al. 1977; Dax et al. 1981; Saggerson, 1986) fat cells. Another study with rats suggests that fasting results in a reduced response to noradrenaline (Giudicelli et al. 1982). This apparent discrepancy is probably due to a change which develops as fasting proceeds, with a decrease in response occurring around $72 \mathrm{~h}$ of fasting. This is supported by a detailed study with hamsters in which fasting had no effect on maximum response during the first $48 \mathrm{~h}$ of fasting but by $72 \mathrm{~h}$ of fasting a decreased response was apparent (Carpene et al. 1990). The apparent discrepancy between effects of fasting on maximum response to catecholamines in vivo and in vitro in humans may be due to the ethical problem of achieving a maximum response in man in vivo.

The mechanism responsible for the enhanced sensitivity of fat cells to catecholamines during fasting has not been elucidated. Unfortunately most studies with rats have involved $72 \mathrm{~h}$ of fasting at which time the response to catecholamine is beginning to decrease. Fasting for $72 \mathrm{~h}$ increased the $\beta$-receptor number of rat fat cells (Giudicelli et al. 1982). Fasting for $48 \mathrm{~h}$ (Gorman et al. 1972) or $72 \mathrm{~h}$ (Dax et al. 1981) increased catecholamine-stimulated adenylate cyclase activity of rat fat cells. Maximum adenylate cyclase activity did not appear to change after $72 \mathrm{~h}$ fasting in rats (Giudicelli et al. 1982), but the ability of $\mathrm{G}_{\mathrm{s}}$ to transmit signals appeared to be enhanced (Lacasa et al. 1986a). Fasting for $72 \mathrm{~h}$ decreased adipose tissue cyclic-AMP phosphodiesterase activity in rats while activation by insulin appeared to be unimpaired (Osegawa et al. 1985). Also cyclic-AMP appears to be less effective in stimulating lipolysis in femoral subcutaneous (but not hypogastric) adipocytes during therapeutic starvation in obese humans (Arner et al. 1981b). Thus, a number of adaptations appear to contribute to the enhanced sensitivity to catecholamines during fasting. In addition to these various biochemical adaptations, fasting also causes profound morphological changes within the fat cell including increased numbers of vesicles within the cytosol (Mizunuma et al. 1981); the role of these vesicles and other morphological adaptations is uncertain but may be involved in facilitating access of hormone-sensitive lipase to its substrate.

The decreased response to catecholamines found on prolonged fasting noted previously may be due to a decrease in fat cell size (Arner et al. 1979) or the development of hypothyroidism, or both. The molecular mechanism responsible for the diminished response to catecholamines has not been elucidated, but does not appear to involve a loss of $\beta$-adrenergic receptors or adenylate cyclase activity, at least in rats (Giudicelli et al. 1982) indicating a defect in the distal portion of the signal transduction system.

In addition to changes in the stimulatory system, fasting decreases the responsiveness of the $\alpha_{2}$-adrenergic system in hamster adipocytes, in part at least, due to a decrease in the number of $\alpha_{2}$-adrenergic receptors (Carpene et al. 1990). In vitro studies with rats 
show a decreased sensitivity to both adenosine and prostaglandin $\mathrm{E}_{1}$ on fasting for 24 or 48 h (Chohan et al. 1984; Saggerson, 1986), but no change in the number or affinity of adenosine receptors (Chohan et al. 1984). On the other hand, Lacasa et al. (1986b) found no evidence for altered ability of adenosine to inhibit adenylate cyclase activity in adipocytes from rats fasted for $72 \mathrm{~h}$. Also Carpene et al. (1990) found the response to adenosine and prostaglandin $E_{1}$ unchanged after a $6 \mathrm{~d}$ fast in hamsters. In man, fasting for $4 \mathrm{~d}$ may induce an increased response to adenosine (Peters et al. 1991), whereas Kather et al. (1985) found no evidence for a change in response or sensitivity to either adenosine or prostaglandin $E_{2}$ in response to energy restriction in obese humans.

Thus, the regulation of lipolysis passes through several phases during fasting. Changes in acute signals (e.g. the fall in serum insulin, and rise in serum glucagon and adrenaline concentrations) occur early on within the first few hours of a fast. The times when the increased sensitivity to catecholamines and glucagon develop are unknown but are clearly chronic, occurring about $24 \mathrm{~h}$ or more after the onset of fasting. In rats, but seemingly not in man, there is initially at least a decreased sensitivity to adenosine and prostaglandins. Prolonged fasting, perhaps due to the development of hypothyroidism, results in a diminished lipolytic response to catecholamines, which could be perceived as part of a general mechanism to minimize nutrient utilization and so prolong survival.

Feeding induces a rapid rise in serum insulin and a decrease in serum glucagon (Unger, 1972; Unger \& Orci, 1976) and adrenaline but no change in noradrenaline (Coppack et al. 1990). Feeding rapidly suppresses lipolysis as assessed from arterio-venous difference measurements of both glycerol and fatty acid release in man (Coppack et al. 1990). In rodents, feeding results in an increase in sympathetic nervous activity in brown adipose tissue at least (this has not been checked in white adipose tissue; Landsberg \& Young, 1985; Barrand \& Callingham, 1987) and an increase in triacylglycerol turnover in white adipose tissue in vivo which can be prevented by the administration of $\beta$-adrenergic antagonists (Brooks et al. 1983); that is, there is a small surge in lipolysis in rodents but with essentially all the fatty acids being re-esterified rather than released into the circulation (Suzuki et al. 1983).

Refeeding fasted rats for $48 \mathrm{~h}$ returned sensitivity to catecholamines to the prefasting value (Zapf et al. 1977, 1981) but the in vitro basal (unstimulated) rate of lipolysis remained elevated despite normal cyclic-AMP concentrations and A-kinase activities (Zapf et al. 1981), indicating some alteration post A-kinase.

Nutrient availability: lactation cycle. Although lactation is a state of markedly elevated food intake, for much of the body it is a state of effective deprivation and in many respects resembles fasting (Table 1). Fat synthesis in adipose tissue is markedly reduced and there is usually a net loss of adipose tissue lipid (Vernon \& Flint, 1984). During lactation serum glucagon does not change, serum growth hormone may rise and serum insulin, glucose and triiodothyronine concentrations are all decreased (Vernon, 1989) and in brown adipose tissue at least there is decreased sympathetic nervous activity (Trayhurn \& Wusteman, 1987), all reminiscent of the fasting state. In ruminants lactation may result in an enhanced response to catecholamines and an increase in the number of $\beta$-adrenergic receptors (Vernon \& Sasaki, 1991) possibly due to increased serum growth hormone levels (Watt et al. 1991), but in the rat response and sensitivity to catecholamines is unchanged (Vernon \& Flint, 1984). Cyclic-AMP phosphodiesterase activity falls during lactation in rats (Aitchison et al. 1982) and the number of $\beta$-adrenergic receptors increases (Watt et al. 1989), both of which might be expected to 
increase the response or sensitivity to catecholamines. Recently we have found that the maximum adenylate cyclase activity falls during lactation and this appears to counteract the effects of the other adaptations, because the ability of catecholamines to activate A-kinase is unchanged.

Removal of the litter from lactating rats has similar effects to re-feeding fasting rats in that serum insulin and glucose concentrations are restored and there is a massive increase in the rate of lipid synthesis in adipose tissue (Vernon \& Flint, 1984). However, in contrast to re-feeding fasted rats, litter removal results in a marked decrease in the response (but not sensitivity) of lipolysis to catecholamines which can be prevented by treatment with growth hormone (Vernon et al. 1987). Litter removal results in a fall in the number of $\beta$-adrenergic receptors of fat cells (Watt et al. 1989; Ros et al. 1992), restoration of adenylate cyclase activity and an increase in cyclic-AMP phosphodiesterase activity (R. G. Vernon, P. W. Watt and E. Finley, unpublished results). Despite these changes, the ability of catecholamines to activate A-kinase is unaltered, indicating that the main constraint is downstream of A-kinase. Our recent results have shown that this constraint does not result from changes in protein phosphatase activity or AMP-stimulated kinase activity which might influence hormone-sensitive lipase activity. Recent results show that there is no change in measurable hormone-sensitive lipase activity in adipose tissue homogenates made from tissue after exposure to catecholamines, but the distribution of the enzyme in the cell is altered, with less being associated with the fat cake in tissue from litter-removed rats (L. Piperova and R. G. Vernon, unpublished results). This suggests an important control point at the level of hormone-sensitive lipase sequestration on to the lipid droplet or access to its lipid substrate, or both.

Lactation, curiously, also results in an increased response to adenosine which gradually decreases on litter removal (Vernon \& Finley, 1986). The physiological advantage of this is uncertain but it may be a device to prevent the animal depleting its lipid reserves too rapidly. The hypothyroidism of lactation is a possible cause but preliminary studies do not support this. Growth hormone, however, accelerates restoration of normal response to adenosine during litter removal (Vernon et al. 1987).

Dietary composition. Serum insulin concentration varies directly with the carbohydrate content of the diet, whereas serum glucagon tends to decrease as the carbohydrate content increases (Unger \& Orci, 1976). Such variations, however, are small compared with those found on fasting. Sympathetic nervous activity in white adipose tissue, on the other hand, appears to be impervious to the relative amount of fat and carbohydrate in the diet but is increased by low-protein diets (Vander Tuig \& Romsos, 1984). The nature of dietary carbohydrate does not appear to alter sympathetic nervous activity, at least in brown adipose tissue (Walgren et al. 1987). Whether these responses to dietary composition have any significance for lipolysis is not clear.

Diet can also alter the ability of fat cells to transmit signals. Feeding rats diets containing a large amount of saturated fat (usually lard) results in a smaller maximum lipolytic response to catecholamines but no change in sensitivity compared with animals fed on carbohydrate-rich diets (Gorman et al. 1972, 1973; Smith et al. 1974; Susini et al. 1979; Tepperman et al. 1986) and a decreased response to the anti-lipolytic effect of insulin (Smith et al. 1974) in one study but not in others (Susini et al. 1979; Tepperman et al. 1986). Gorman et al. (1973) found no change in ligand binding to the $\beta$-receptor or in maximum basal adenylate cyclase activity but there was a diminished ability to activate 
adenylate cyclase by adrenaline in fat cells from fat-fed rats suggesting a limitation at the level of $\mathrm{G}_{\mathrm{s}}$.

Studies with human adipose tissue revealed no differences in response or sensitivity to catecholamines after eating fat-rich or carbohydrate-rich diets for $7 \mathrm{~d}$ (Kather et al. 1987); in this study, in contrast to those with rats, the authors found that the fat-rich diet enhanced the response to the anti-lipolytic effect on insulin.

Other studies suggest that it is the nature of the fatty acids rather than the amount of fat in the diet which is important, as diets rich in polyunsaturated fats result in a much greater lipolytic response to catecholamines than diets rich in saturated fat (Carreau et al. 1972; Awad \& Zepp, 1979; Awad \& Chattopadhyay, 1986; Parrish et al. 1991). Decreased adenylate cyclase, cyclic-AMP phosphodiesterase and hormone-sensitive lipase (Awad \& Chattopadhyay, 1986) may all contribute to the decreased responsiveness of fat cells from rats fed on diets rich in saturated fats. Changes in adenylate cyclase at least may be due to changes in membrane fluidity (Nicolas et al. 1990). Changes in membrane fluidity also alter insulin binding and action in adipocytes (Clandinin et al. 1991) and $\beta$-receptor number in other tissues at least (Peters, 1988; Murphy, 1990).

\section{CONCLUSIONS}

The rate of lipolysis is, thus, subject to a surprisingly large range of acute and also chronic controls, which may be altered by the nutrient availability (energy status) and to a lesser extent by dietary composition, particularly by diets containing a large amount of saturated fat. Nutrient availability or composition is likely to influence lipolysis initially by altering the concentration of acute modulators, but can also lead to changes in response or sensitivity to these acutely acting factors through changes in chronically acting hormones or membrane fluidity, or both. Adaptations may occur in both the stimulatory pathways and in the inhibitory (e.g. adenosine) pathways, and in general do not appear to involve a change in a single component, rather the activity or amount of several components may be altered, sometimes paradoxically with counteracting effects. The chronically-acting hormones responsible for these adaptations of the signal transduction systems have not been resolved. As well as biochemical changes, changes in energy balance can also have marked effects on adipocyte morphology, the physiological significance of which is not yet understood.

\section{REFERENCES}

Aitchison, R. E. D., Clegg, R. A. \& Vernon, R. G. (1982). Lipolysis in rat adipocytes during pregnancy and lactation. Biochemical Journal 202, 243-247.

Andrews, J., Kashiwagi, A., Verso, M. A., Vasquez, B., Howard, B. V. \& Foley, J. E. (1984). Elfects of four-day fast on triglyceride mobilization in human adipocytes. International Journal of Obesity 8, 355-363.

Arner, P., Engfeldt, P. \& Nowak, J. (1981a). In vivo observations on the lipolytic effect of noradrenaline during therapeutic fasting. Journal of Clinical Endocrinology and Metabolism 53, 1207-1212.

Arner, P., Engfeldt, P. \& Ostman, J. (1979). Relationship between lipolysis, cyclic AMP, and fat-cell size in human adipose tissue during fasting and in diabetes mellitus. Metabolism 28, 198-209.

Arner, P., Engfeldt, P., Wennlund, A. \& Ostman, J. (1981b). Post receptor activation of lipolysis in starvation, diabetes mellitus and hyperthyroidism. Hormone and Metabolism Research 13, 272-276.

Awad, A. B. \& Chattopadhyay, J. P. (1986). Effect of dietary saturated fatty acids on hormone-sensitive lipolysis in rat adipocytes. Journal of Nutrition 116, 1088-1094. 
Awad, A. B. \& Zepp, E. A. (1979). Alteration of rat adipose tissue lipolytic response to norepinephrine by dietary fatty acid manipulation. Biochemical and Biophysical Research Communications 86, 138-144.

Barrand, M. A. \& Callingham, B. A. (1983). The catecholamines: adrenaline, noradrenaline and dopamine. In Hormones in Blood, vol. 5, 3rd ed., pp. 55-123 [C. H. Gray and V. H. T. James, editors]. London: Academic Press.

Bray, G. A. \& Nishizawa, Y. (1978). Ventromedial hypothalamus modulates fat mobilization during fasting. Nature 274, 900-901.

Brooks, B. J., Arch, J. R. S. \& Newsholme, E. A. (1983). Effect of some hormones on the rate of the triacylglycerol/fatty-acid substrate cycle in adipose tissue of the mouse in vivo. Bioscience Reports 3 , 263-267.

Carpene, C., Galitzky, J., Saulnier-Blache, J.-S. \& Lafontan, M. (1990). Selective reduction of $\alpha_{2}$-adrenergic responsiveness in hamster adipose tissue during prolonged starvation. American Journal of Physiology 259 , E80-E88.

Carreau, J. P., Loriette, C., Counis, R. \& Ketevi, P. (1972). Demasquage des recepteurs de la noradrenaline par enrichissement en acide linoleique des phospholipides membranaires de la cellule adipeuse (Relative non-masking of noradrenaline receptors by linoleic acid-rich phospholipids in fat cell membranes). Biochimica et Biophysica Acta 280, 440-443.

Chohan, P., Carpenter, C. \& Saggerson, E. D. (1984). Changes in the anti-lipolytic action and binding to plasma membranes of $\mathrm{N}^{6}$-L-phenylisopropyladenosine in adipocytes from starved and hypothyroid rats. Biochemical Journal 223, 53-59.

Clandinin, M. T., Cheema, S., Field, C. J., Garg, M. L., Venkatraman, J. \& Clandinin, T. R. (1991). Dietary fat: exogenous determination of membrane structure and cell function. FASEB Journal 5, 2761-2769.

Coppack, S. W., Fisher, R. M., Gibbons, G. F., Humphreys, S. M., McDonough, M. J., Potts, J. L. \& Frayn, K. N. (1990). Postprandial substrate deposition in human forearm and adipose tissues in vivo. Clinical Science 79, 339-348.

Correze, C. \& Thibout, H. (1985). Effects of thyroidectomy, insulin, and phospholipids on cyclic AMP phosphodiesterase in rat adipocyte plasma membranes. Journal of Cyclic Nucleotide and Protein Phosphorylation Research 10, 167-178.

Dax, E. M., Partilla, J. S. \& Gregerman, R. I. (1981). Increased sensitivity of epinephrine stimulated lipolysis during starvation: tighter coupling of the adenylate cyclase complex. Biochemical and Biophysical Research Communications 101, 1186-1192.

Degerman, E., Smith, C. J., Tornqvist, H., Vasta, V., Belfrage, P. \& Manganiello, V. C. (1990). Evidence that insulin and isoprenaline activate the cGMP-inhibited low- $\mathrm{K}_{\mathrm{m}} \mathrm{cAMP}$ phosphodiesterase in rat fat cells by phosphorylation. Proceedings of the National Academy of Science, USA 87, 533-537.

De Mazancourt, P., Lacasa, D., Giot, J. \& Giudicelli, Y. (1989). Role of adenosine 3' 5' -monophosphate and the $R_{i}$-receptor $G_{i}$-coupled adenylate cyclase inhibitory pathway in the mechanism whereby adrenalectomy increases the adenosine antilipolytic effect in rat fat cells. Endocrinology 124, 1131-1139.

Engfeldt, P., Arner, P., Bolinder, J., Wennlund, A. \& Ostman, J. (1982). Phosphodiesterase activity in human subcutaneous adipose tissue in hyper- and hypothyroidism. Journal of Clinical Endocrinology and Metabolism 54, 625-629.

Franke, W. W., Hergt, M. \& Grund, C. (1987). Rearrangement of the vimentin cytoskeleton during adipose conversion: formation of intermediate filament cage around lipid droplets. Cell 49, 131-141.

Fredholm, B. B., Birgitta, L. \& Persson, B. (1973). Effects of fasting on adipose tissue perfused in situ in young dogs. Scandinavian Journal of Clinical Laboratory Investigations 31, 79-86.

Garton, A. J., Campbell, D. G., Carling, D., Hardie, D. G., Colbran, R. J. \& Yeaman, S. J. (1989). Phosphorylation of bovine hormone-sensitive lipase by the AMP-activated protein kinase. European Journal of Biochemistry 179, 249-254.

Giudicelli, Y., Lacasa, D. \& Agli, B. (1982). Alterations induced by a prolonged fasting: opposite effects on the $\beta$-adrenergic receptor-coupled adenylate-cyclase system and on lipolysis in fat cells from rat. European Journal of Biochemistry 121, 301-308.

Giudicelli, Y., Lacasa, D., De Mazancourt, P., Pasquier, Y. N. \& Pecquery, R. (1989). Steroid hormones and lipolysis regulation. In Obesity in Europe 88, pp. 185-194 [P. Bjorntorp and S. Rossner, editors]. London: John Libbey.

Gorman, R. R., Tepperman, H. M. \& Tepperman, J. (1972). Effects of starvation, refeeding, and fat feeding on adipocyte ghost adenyl cyclase activity. Journal of Lipid Research 13, 276-280.

Gorman, R. R., Tepperman, H. M. \& Tepperman, J. (1973). Epinephrine binding and the selective restoration of adenylate cyclase activity in fat-fed rats. Journal of Lipid Research 14, 279-285. 
Greenberg, A. S., Egan, J. J., Wek, S. A., Garty, N. B., Blanchette-Mackie, E. J. \& Londos, C. (1991). Perilipin, a major hormonally regulated adipocyte-specific phosphoprotein associated with the periphery of lipid storage droplets. Journal of Biological Chemistry 266, 11341-11346.

Hales, C. N., Luzio, J. P. \& Siddle, K. (1978). Hormonal control of adipose tissue lipolysis. Biochemical Society Symposia 43, 97-135.

Hardie, D. G. (1989). Regulation of fatty acid synthesis via phosphorylation of acetyl-CoA carboxylase. Progress in Lipid Research 28, 117-146.

Jensen, M. D., Haymond, M. W., Gerich, J. E., Cryer, P. E. \& Miles, J. M. (1987). Lipolysis during fasting: decreased suppression by insulin and increased stimulation by epinephrine. Journal of Clinical Investigation 79, 207-213.

Jung, R. T., Shetty, P. S., Barrand, M., Callingham, B. A. \& James, P. T. (1979). The role of catecholamines and thyroid hormones in the metabolic response to semistarvation. Proceedings of the Nutrition Society 38, $17 \mathrm{~A}$.

Kather, H., Wieland, E., Fisher, B. \& Schlierf, G. (1985). Antilipolytic effects of $\mathrm{N}^{6}$-phenylisopropyladenosine and prostaglandin $E_{2}$ in fat-cells of obese volunteers before and during energy restriction. Biochemical Journal 231, 531-535.

Kather, H., Wieland, E., Scheurer, A., Vogel, G., Wildenberg, U. \& Joost, C. (1987). Influences of variation in total energy intake and dietary composition on regulation of fat cell lipolysis in ideal-weight subjects. Journal of Clinical Investigation 80, 566-572.

Klein, S., Holland, O. B. \& Wolfe, R. R. (1990). Importance of blood glucose concentration in regulating lipolysis during fasting in humans. American Journal of Physiology 21, E32-E39.

Klein, S., Peters, E. J., Holland, O. B. \& Wolfe, R. R. (1989). Effect of short- and long-term $\beta$-adrenergic blockade on lipolysis during fasting in humans. American Journal of Physiology 20, E65-E73.

Kozlowski, S., Kowalik-Borowka, E., Nazar, K., Falecka-Wieczorek, I., Stephens, D. \& Kaciuba-Uscilko, H. (1985). Effect of beta-adrenergic blockade on lipid mobilization induced by fasting in dogs. Hormone and Metabolic Research 17, 8-11.

Lacasa, D., Agli, B. \& Giudicelli, Y. (1986a). Increased sensitivity of fat cell adenylate cyclase to stimulatory agonists during fasting is not related to impaired inhibitory coupling system. FEBS Letters 202, 260-266.

Lacasa, D., Agli, B. \& Giudicelli, Y. (1986b). Fasting increases fat cell adenylate cyclase sensitivity to stimulatory agonists through enhanced ability of the stimulatory regulatory component $N_{s}$ to dissociate. Biochemical and Biophysical Research Communications 138, 1411-1419.

Lacasa, D., Agli, B., Pecquery, R. \& Giudicelli, Y. (1991). Influence of ovariectomy and regional fat distribution on the membranous transducing system controlling lipolysis in rat fat cells. Endocrinology 128, 747-753.

Landsberg, L. \& Young, J. B. (1985). The influence of diet on the sympathetic nervous system. In Neuroendocrine Perspectives, vol. 4, pp. 191-218 [E. E. Muller, R. M. MacLeod and L. A. Frohman, editors]. London: Elsevier Science Publishers.

Lonnroth, P., Jansson, P.-A., Fredholm, B. B. \& Smith, U. (1989). Microdialysis of intercellular adenosine concentration in subcutaneous tissue in humans. American Journal of Physiology 256, E250-E255.

Malbon, C. C., Rapiejko, P. J. \& Watkins, D. C. (1988). Permissive hormone regulation of hormone-sensitive effector systems. Trends in Pharmacological Sciences 9, 33-36.

Milligan, G. \& Saggerson, E. D. (1990). Concurrent up-regulation of guanine-nucleotide-binding proteins $\mathrm{G}_{\mathrm{i}} 1 a, \mathrm{G}_{\mathrm{i}} 2 a$ and $\mathrm{G}_{\mathrm{i}} 3 a$ in adipocytes of hypothyroid rats. Biochemical Journal 270, 765-769.

Mizunuma, T., Takahashi, Y. \& Kishino, Y. (1981). Morphological studies on isolated rat adipocytes. I. Effect of starvation. Acta Histochemistry and Cytochemistry 14, 101-108.

Murphy, M. G. (1990). Dietary fatty acids and membrane protein function. Journal of Nutrition and Biochemistry 1, 68-79.

Nicolas, C., Demarne, Y., Lecourtier, M.-J. \& Lhuillery, C. (1990). Specific alterations in different adipose tissues of pig adipocyte plasma membrane structure by dietary lipids. International Journal of Obesity 14, 537-549.

Ninomiya, H., Morimoto, C., Tsujita, T., Sumida, M. \& Okuda, H. (1990). Biomodulator-mediated susceptibility of endogenous lipid droplets from rat adipocytes to hormone-sensitive lipase. Biochemical Medicine and Metabolic Biology 43, 112-127.

Oschry, Y. \& Shapiro, B. (1980). Lipolytic activity in adipocyte cell fractions. Biochimica et Biophysica Acta 618, 293-299.

Osegawa, M., Makino, H., Kanatsuka, A., Suzuki, T., Hashimoto, N. \& Yoshida, S. (1985). Modulation of insulin action by fasting: A study using a phosphodiesterase activation system in rat fat cells. Hormone and Metabolic Research 17, 633-636. 
Parrish, C. C., Pathy, D. A., Parkes, J. G. \& Angel, A. (1991). Dietary fish oils modify adipocyte structure and function. Journal of Cellular Physiology 148, 493-502.

Peters, R. (1988). Lateral mobility of proteins and lipids in the red cell membrane and the activation of adenylate cyclase by $\beta$-adrenergic receptors. FEBS Letters $234,1-7$.

Peters, E. J., Klein, S. \& Wolfe, R. R. (1991). Effect of short-term fasting on the lipolytic response to theophylline. American Journal of Physiology 261, E500-E504.

Ros, M., Alonso, G. \& Moreno, F. J. (1992). Effects of litter removal on the lipolytic response and the regulatory components of the adenylate cyclase in adipocytes isolated from lactating rats. Biochemical Journal 281, 333-337.

Ros, M., Northrup, J. K. \& Malbon, C. C. (1989), Adipocyte G-proteins and adenylate cyclase. Biochemical Journal 257, 737-744.

Roth, N. S., Campbell, P. T., Caron, M. G., Lefkowitz, R. J. \& Lohse, M. J. (1991). Comparative rates of desensitization of $\beta$-adrenergic receptor kinase and the cyclic AMP-dependent protein kinase. Proceedings of the National Academy of Science, USA 88, 6201-6204.

Saggerson, E. D. (1980). Increased antilipolytic effect of the adenosine 'R-site' agonist $N^{6}$-(phenylisopropyl) adenosine in adipocytes from adrenalectomised rats. FEBS Letters 115, 127-128.

Saggerson, E. D. (1986). Sensitivity of adipocyte lipolysis to stimulatory and inhibitory agonists in hypothyroidism and starvation. Biochemical Journal 238, 387-394.

Saggerson, E. D. (1989). Alterations in the regulation of lipolysis in brown and white adipose tissue in the diabetic state. Biochemical Society Transactions 17, 47-48.

Sechen, S. J., Dunshea, F. R. \& Bauman, D. E. (1990). Somatotropin in lactating cows: effect on response to epinephrine and insulin. American Journal of Physiology 258, E582-E588.

Shetty, P. S. (1990). Physiological mechanisms in the adaptive response of metabolic rates to energy restriction. Nutrition Research Reviews 3, 49-74.

Slavin, B. G. (1972). The cytophysiology of mammalian adipose cells. International Reviews of Cytology 33, 297-334.

Smith, U., Kral, J. \& Bjorntorp, P. (1974). Influence of dietary fat and carbohydrate on the metabolism of adipocytes of different size in the rat. Biochimica et Biophysica Acta 337, 278-285.

Stralfors, P. \& Honnor, R. C. (1989). Insulin-induced dephosphorylation of hormone-sensitive lipase. European Journal of Biochemistry 182, 379-385.

Strassheim, D., Milligan, G. \& Houslay, M. D. (1990). Diabetes abolishes the GTP-dependent, but not the receptor-dependent inhibitory function of the inhibitory guanine-nucleotide-binding regulatory protein $\left(G_{i}\right)$ on adipocyte adenylate cyclase activity. Biochemical Journal 266, 521-526.

Susini, C., Lavau, M. \& Herzog, J. (1979). Adrenaline responsiveness of glucose metabolism in insulinresistant adipose tissue of rats fed a high-fat diet. Biochemical Journal 180, 431-433.

Suzuki, M., Shimomura, Y. \& Satoh, Y. (1983). Diurnal changes in lipolytic activity of isolated fat cells and their increased responsiveness to epinephrine and theophylline with meal feeding in rats. Journal of Nutritional, Science and Vitaminology 29, 399-411.

Tepperman, H. M., Dewitt, J. \& Tepperman, J. (1986). Effect of a high fat diet on rat adipocyte lipolysis: Responses to epinephrine, forskolin, methylisobutylxanthine, dibutyryl cyclic AMP, insulin and nicotinic acid. Journal of Nutrition 116, 1984-1991.

Trayhurn, P. \& Wusteman, M. C. (1987). Sympathetic activity in brown adipose tissue during lactation in mice. Proceedings of the Nutrition Society 46, 27 A.

Unger, R. H. (1972). Insulin/glucagon ratio. Israeli Journal of Medical Science 8, 252-257.

Unger, R. H. \& Orci, L. (1976). Physiology and pathophysiology of glucagon. Physiological Reviews 56, $778-826$.

Van der Tuig, J. G. \& Romsos, D. R. (1984). Effects of dietary carbohydrate, fat, and protein on norepinephrine turnover in rats. Metabolism 33, 26-33.

Vernon, R. G. (1980). Lipid metabolism in the adipose tissue of ruminant animals. Progress in Lipid Research $19,23-106$.

Vernon, R. G. (1989). Endocrine control of metabolic adaptation during lactation. Proceedings of the Nutrition Society 48, 23-32.

Vernon, R. G. (1992). Control of lipogenesis and lipolysis. In The Control of Fat and Lean Deposition [P. J. Buttery, K. N. Boorman and D. B. Lindsay, editors]. London: Butterworths (In the Press).

Vernon, R. G. \& Clegg, R. A. (1985). The metabolism of white adipose tissue in vivo and in vitro. In New Perspectives in Adipose Tissue, pp. 65-86 [A. Cryer and R. L. R. Van, editors]. London: Butterworths. 
Vernon, R. G. \& Finley, E. (1986). Lipolysis in rat adipocytes during recovery from lactation. Biochemical Journal 234, 229-231.

Vernon, R. G., Finley, E. \& Flint, D. J. (1987). Role of growth hormone in the adaptations of lipolysis in rat adipocytes during recovery from lactation. Biochemical Journal 242, 931-934.

Vernon, R. G. \& Flint, D. J. (1984). Adipose tissue: metabolic adaptation during lactation. Symposium of the Zoological Society of London 51, 119-145.

Vernon, R. G. \& Sasaki, S. (1991). Control of responsiveness of tissues to hormones. In Physiological Aspects of Digestion and Metabolism in Ruminants, pp. 155-182 [T. Tsuda, Y. Sasaki and R. Kawashima, editors]. London: Academic Press.

Walgren, M. C., Young, J. B., Kaufman, L. N. \& Landsberg, L. (1987). The effects of various carbohydrates on sympathetic activity in heart and interscapular brown adipose tissue of the rat. Metabolism 36, 585-594.

Watt, P. W., Finley, E., Cork, S., Clegg, R. A. \& Vernon, R. G. (1991). Chronic control of the $\beta$ - and $\alpha_{2}$-adrenergic systems of sheep adipose tissue by growth hormone and insulin. Biochemical Journal 273, 39-42.

Watt, P. W., Madon, R. J., Flint, D. J. \& Vernon, R. G. (1989). Effects of growth hormone on the $\beta$-adrenergic receptor number of rat adipocyte membranes. Biochemical Society Transactions 18, 486.

Wolfe, R. R., Peters, E. J., Klein, S., Holland, O. B., Rosenblatt, J. \& Gray, H. (1987). Effect of short-term fasting on lipolytic responsiveness in normal and obese human subjects. American Journal of Physiology 252, E189-E196.

Young, J. B., Rosa, R. M. \& Landsberg, L. (1984). Dissociation of sympathetic nervous system and adrenal medullary responses. American Journal of Physiology 247, E35-E40.

Xu, X., De Pergola, G. \& Bjorntorp, P. (1991). Testosterone increases lipolysis and the number of $\beta$-adrenoceptors in male rat adipocytes. Endocrinology 128, 379-382.

Zapf, J., Waldvogel, M. \& Froesch, E. R. (1977). Increased sensitivity of rat adipose tissue to the lipolytic action of epinephrine during fasting and its reversal during refeeding. FEBS Letters 76, 135-138.

Zapf, J., Waldvogel, M. \& Froesch, E. R. (1981). Is increased basal lipolysis in adipose tissue of fasted-refed rats related to cyclic-AMP-dependent mehanisms? European Journal of Biochemistry 119, 453-459. 